\title{
Satisfaction among Residents of Elderly Homes in
}

\section{Alexandria}

Nahed Mohamed Saied Ayoub*, Heba Mahmoud El Kady**

\begin{abstract}
Satisfaction among residents of institutions is an important issue. Several factors affect the elderly satisfaction as socio-demographic characteristics, health status, expectations about care, the structure, the process and the out come of the services. The present study aimed to assess the degree of satisfaction among elderly homes' residents in Alexandria. The sample included all elders living in the governmental homes in Alexandria who accepted to participate in the study. Data was collected using a structured interview sheet to obtain information about the general characteristics of the elderly, assessment of their functional abilities, and a consumer satisfaction tool which was translated and tested for content validity and reliability. The results revealed that the majority of the residents were either satisfied or very satisfied with the total satisfaction score of all satisfaction's domains (48.9\%, $43.1 \%$ respectively), while only $8.1 \%$ of the elderly were dissatisfied. Recommendation: Regular monitoring and evaluation of services provided at the elderly homes to ensure a best quality of care at them.
\end{abstract}

\section{INTRODUCTION:}

Life expectancy had risen sharply during the twentieth century and is expected to continue to rise, in virtually all populations throughout the world, where the population over 65 years increases by $2.5 \%$ per year. In the developed countries, $12.6 \%$ of the populations are elders compared to only $4.6 \%$ in the developing ones. ${ }^{(1,2)}$ In Egypt, the percentage of those aged 60 years and over represent $5.8 \%$ of the total population and is expected to reach more than $10 \%$ by the year 2025. ${ }^{(3)}$

The percentage of elders living in institutions dramatically increases with age. ${ }^{(4)}$ In USA, the percentage of persons aged 65 years or older living in institutions

\footnotetext{
*Lecturer of gerontological Nursing, Faculty of Nursing Mansoura University.

${ }^{* *}$ Lecturer of Geriatric Health, Family Health Department, High Institute of Public Health.
} 
represent 5\%, while in UK it represents $6.3 \% .{ }^{(5,6)}$ On the other hand, this percentage reaches $1 \%$ in Egypt, $1.4 \%$ in United Arab Emirates, and 1.3\% in Bahrain. (7-9) In Alexandria, the rate of institutionalization was estimated to reach 0.2 per 1000 elderly persons 60 years of age or older.(10) Institutions provide the elders with a shelter, assistance with activities of daily living, meal and house keeping services. They also provide care for the disabled, occupational and physical therapy, in addition to social and psychological support.(11) In spite of these services, there are some shortcomings of these homes. They may increase the family separation, increase dependency of the elders, and may dehumanize the elders by destroying their defined role in the family and community thus they lose their sense of identity and security. ${ }^{(12)}$

One of the main aims of the institutions is meeting the needs and expectations of the consumer. The role of the client in the health care and social services system is evolving, "patients/clients" became consumers and are now often referred to as "consumers". The emphasis on the consumer's perspective has created a demand for information on consumer experiences and satisfaction with health and social services.(11) This evolution towards consumer focus has also increased the importance of measuring satisfaction with care for older adults. ${ }^{(13)}$ Patient satisfaction is a primary outcome that may be defined as the extent to which an individual's needs and wants are met.(14) Elderly satisfaction is the degree of congruency between consumer's expectations of ideal care and the perception of real care he or she receives. Satisfaction results from meeting or exceeding consumer's expectations. Patient satisfaction is an important consideration that is closely related to consumer care efficiency. Measuring consumer satisfaction can provide useful 
information about the structure, process, and out come of the services provided. ${ }^{(15)}$ By identifying sources of consumer's dissatisfaction, the organization can address system weakness thus improving its risk management. ${ }^{(16)}$

Measures of patient satisfaction are increasingly being used to assess the competency of health care providers and the quality of care, particularly as satisfaction relates to continuity of care. Numerous factors have been related to consumer satisfaction. These include socio-demographic characteristics, health status, expectation about care, and the structure, process, and out come of the services. Meeting and exceeding consumer expectations is a top priority of any institution. (17) Assessing the satisfaction of institutionalized elders can help health team members in planning, sponsoring and evaluating programs and services in order to provide a health -enhancing environment. (18)
Aim of the study: The present study aimed to assess the degree of satisfaction among elderly homes' residents in Alexandria

\section{Subjects and Methods:}

\section{Study design:}

A descriptive cross sectional study was carried out.

\section{I- Setting:}

The study was carried out in all the governmental elderly homes in Alexandria namely: Dar El Hadaya, Dar El Hana, Dar El Saada, Dar El Hanan, Dar El Regal, and Dar El Nour elderly homes in Alexandria.

\section{II- Subjects:}

The sample included all residents in the previously mentioned settings who were able to communicate, and accepted to participate in the study. The sample size from different homes amounted to 123 residents.

\section{III- Tools:}

Two tools were used to collect the data: Tool I: This tool consisted of three 
parts:

A- A structured interview sheet was developed by researchers to obtain

information about:

1- Socio-demographic characteristics of the elderly.

2- Source of income.

3- Reason of admission to the elderly home.

4- Feeling of the elder after admission.

B- Katz scale for activities of daily living (ADLS):(19)

The Katz scale was used to assess degree of dependency in performing activities of daily living. It included data about the basic daily activities of the elderly as bathing, dressing, toileting, transfer, urinary and feacal continence and feeding. The six different functions are measured and scored according to the individual's actual performance of these functions. They are categorized into three levels of dependency: each item was scored from zero to two, where two indicates full independence i.e. the ability to perform the task without human assistance, one indicates that the patient needs assistance i.e. the ability to perform the task with some help, and zero indicates total dependence i.e. the inability to perform the task even with assistance.

The total score of the scale was from 0-12. According to the scale, patients were classified into three categories:

1- Totally independent: score 9-12

2- Partially dependent: 5-8

3- Totally dependent: 0-4

C- Lawton and Brady scale of instrumental activities of daily living (IADLs) $^{(20)}$

Lawton scale was used to assess instrumental activities of daily living. The scale includes eight items: ability to use the telephone, go shopping, food preparation, house keeping, laundry, transportation, responsibility for own medication and ability to handle finances.

The answers were given a score according 
to the response as follows:

- Able (2)

- Unable (1)

The maximum score was 16 for females and 10 for males. Six points from the maximum score were subtracted for males for gender-specific questions. The score achieved by the elder was calculated as a percentage from the maximum score of his category representing $100 \%$. The degree of the elder's performance of IADL was categorized as follows: totally dependent $(0-<25 \%)$, partially dependent $(25-<75 \%)$, independent ( $\geq 75 \%)$.

Tool II: - A consumer satisfaction scale (2006): (21) was used to measure the residents' satisfaction at homes for the elderly. It consists of six domains: satisfaction with staff and administration of the home, satisfaction with physical aspect of the nursing home, satisfaction with the activities available to residents, satisfaction with the personal care provided to residents, satisfaction with food and meals, and satisfaction with resident's personal rights. Respondents rate their satisfaction on a five point scale ranging from 1 to 5 , with $1=$ very dissatisfied, $2=$ dissatisfied, $3=$ neutral (neither satisfied nor dissatisfied), $4=$ satisfied, $5=$ very satisfied. The maximum total satisfaction score was 215 . Scores from $0-<25 \%$ of the total score indicated poor satisfaction, scores from 25$<75 \%$ of the total score indicated moderate satisfaction, and scores $\geq 75 \%$ of the total score indicated high satisfaction.

\section{Methods:}

1. Official permissions were obtained from the managers of the elderly homes.

2. Satisfaction scale was translated into Arabic, and validated by the juries including five experts in administration and gerontological nursing. The required corrections and modifications were carried out accordingly.

3. Satisfaction scale was tested for its reliability. Test-retest was used; 
coefficient factor " $r$ " was calculated using the Pearson's Coefficient of Correlation 0.8.

4. A pilot study was carried out on 20 clients in the selected homes to ascertain clarity, applicability of the tool, and to estimate the time needed to complete the questionnaire. The pilot subjects were not included in the main studied sample.

5. Each resident was interviewed individually after explanation of the purpose and method of the study and obtaining his or her oral consent in order to participate in the study, confidentiality was secured. Each individual interview took about 20 minutes. The participant had the right to leave from the research at any time.

6. Data were collected during the period of four months from the begging of December 2008 to March 2009.

\section{Statistical analysis:}

Data were analyzed using SPSS software version 13.0. Descriptive statistics as proportion, mean and standard deviation were used. The Kolmogorov-Smirnov test was used to examine the normality of the shape of satisfaction score distribution. As the distribution was not normal so, nonparametric measures were used. The Mann-Whitney test was used for comparison of satisfaction score between two groups and the Kruskal-Wallis test was used in case of more than two groups. All reported $p$ values are two-tailed. The level of significance was set at 0.05 .

\section{Results:}

Table 1: illustrates the general characteristics of the residents of the elderly homes. It demonstrates that about two thirds of the residents had a mean age of $69.8 \pm 5.9,61.8 \%$ were females, $62.6 \%$ were widowed, $74.8 \%$ were illiterate or could only read and write, $57.7 \%$ were housewives, and $73.2 \%$ had sons or daughters. It also shows that the monthly income of more than one third of the 
sample $(39.8 \%)$ ranged from 400 to less than 600 pounds/month, and the source of income for most of the sample (93.5\%) was pension. The table also illustrates that according to Katz for activities of daily living (ADLs) and Lawton scale for instrumental activities of daily living (IADL), most of the sample were independent in performing the ADLs and IADLs (98.4\% and $87.8 \%$ respectively).

Table 2: Shows the distribution of study sample according to admission and social variables. The table shows that the majority of elders (74.8\%) were admitted to the homes by their own will and the highest percentage of elders were admitted due to feeling lonely in their own homes (42.3\%). In addition, the mean length of stay of the elders was $4.02 \pm 2.83$ years. The table also shows that more than half of the sample (52.0\%) had a feeling of loneliness after admission to the home. Concerning the frequency of family visits to the elderly, the modal frequency for visits was once per week (34.1\%). As regards participation of elders in social activities in the homes, the table shows that about two thirds of the sample participated in social activities (60.2\%).

Table 3: illustrates the degree of residents' satisfaction with the different satisfaction domains. The table shows that more than half of the elders were satisfied or very satisfied with the different domains of satisfaction scale. It shows that $35.8 \%$ were very satisfied with administrative aspects, $31.7 \%$ were satisfied with physical environment, 32.5\% very satisfied with available services, $28.5 \%$ satisfied with personal care, $33.3 \%$ satisfied with food services, and $35.8 \%$ satisfied with personal rights.

Table 4: shows distribution of the study sample according to their total satisfaction score. The table shows that about half of the elders were satisfied and the other half were very satisfied $(48.8 \%$ and $43.1 \%$ respectively). Only $8.1 \%$ were 
dissatisfied

Table 5: shows the relation between characteristics of the study sample and the mean score of satisfaction domains. The table shows that the mean total satisfaction score was almost equal among both males and females. It also shows that the highest mean total satisfaction score was among elders aged 80 years and above (150.6 \pm 33.7$)$. Regarding the marital status, the table shows that the highest mean total satisfaction score was among widowed elders (145.9 \pm 48.0$)$. It also shows that the highest mean total satisfaction score was among elders whose income was 600 and more pounds/month (158.7 \pm 40.3$)$. As regards the relation between physical functioning and the mean total satisfaction score, the table revealed that the highest mean total satisfaction scores were among elders with better physical functioning as detected by Katz and Lawton scales (148.6 \pm 46.2 and $144.9 \pm 48.3$ respectively). The only variable that demonstrated a statistically significant relation with the mean total satisfaction score was the instrumental activities of daily living (IADL) $(\mathrm{P}=0.03)$.

Table 6: shows the relation between admission and social variables, and the mean score of satisfaction domains. The table shows that the highest mean total satisfaction score was among elders whose admission was by their own will (156.0 \pm 42.9$)$, who were admitted due to feeling lonely at home (157.8 \pm 42.8$)$, and those whose feeling after admission was just loneliness (166.6 \pm 38.4$)$. The table also shows that the highest mean total satisfaction score was among elders who were more frequently visited by their relatives $(173.0 \pm 32.5)$, and who participated in social activities (169.2 \pm 31.7$)$. The table also reveals that the highest mean total satisfaction score was among elders whose length of stay was 5 or more years (154.4 \pm 39.3$)$.

A statistically significant difference 
was found in the mean total satisfaction score in relation to decision and cause of admission, feeling after admission, length of stay, and participation in social activities.

\section{Discussion:}

Admission to elderly homes is a significant event in lives of older persons and their families. (22) Elderly homes offer skilled and basic nursing care on an ongoing basis. Committee on aging 2000 described elderly homes as being different from other health care services because the aim is to maintain an optimal level of functioning rather than to achieve cure. To achieve this aim, they must provide medical, nursing, social, restorative, and personal services in addition to special housing for those with some functional impairment or skilled nursing needs. Gerontological nurses have an important role to play in this setting. (23) Their goal is promoting the highest quality of services for all residents by identifying points of weakness and strength in the provided services. The aim of this study was to assess the degree of satisfaction among elderly homes' residents in Alexandria.

Regarding sex, the present study showed that about two thirds of the residents were females (61.8\%) and more than half aged 60 to less than 70 years (55.3\%) (Table 1). This finding differs from a study carried out in the USA (22) which mentioned that males were the primary residents of elderly homes. This may be due to the finding that about two thirds of the residents were widowed (62.6\%)(Table1) and about one third (32.5\%) were admitted due to absence of a caregiver at home (Table 2). Regarding physical functioning, the present study demonstrates that most of the sample was independent in performing both activities of daily living (ADLs), and instrumental activities of daily living (IADLs) (Table1). This differs from a study in USA (24) where the majority of residents $(80 \%)$ were functionally dependent. This difference 
may be due to that the rules of all of the studied elderly homes mentioned that it is not permit to admit the independent elderly, especially the independent in performing activities of daily living.

The present study showed that the most common reason for elders admission was feeling lonely at own home and the least common reason was absence of caregiver, this is due to the culture and norms in Eastern communities which consider it a shame for the children to let their parents live in elderly homes (table2).

The present study demonstrates that more than half of the sample $(52.0 \%)$ felt lonely after admission, and the other half had a feeling of grief and misery $(48.0 \%)$ (Table2). This may be attributed to the fact that relocation of elders is a stressful event and may even cause a psychic trauma to some of them. This result is in agreement with other studies that report that depressive symptoms such as anger, loneliness, fear, and weeping were accompanied with admission to the geriatric homes. ${ }^{(25-27)}$.

Elders' satisfaction is a prerequisite for quality care as they are the central users of elderly homes and therefore the assessment of elderly perceived quality of residential care is important for evaluation of delivered services. (28) However, elders can't be viewed as a homogenous group with similar needs and capacities therefore their satisfaction is influenced by many factors. ${ }^{(29)}$

The main factor that might cause adverse effect on satisfaction of institutionalized elders is the quality of relationship with institution's workers and caregivers, (30) however, the present study revealed that more than one third of the residents were very satisfied with staff and administration of the elders' home(table 3). This may be due to the fact that some elders were reluctant to express dissatisfaction in case their future medical or nursing care was compromised. This 
goes with previous studies $(31,29)$ which mentioned that elders demonstrate considerable loyalty to their care providers and administrative staff whom they often viewed not solely as professionals but as good and valued friends as well. Also, personal interactions with helping workers and actual caregivers appear to be a significant predictor of elders' satisfaction rather than elder's approval of the actual care provided.

The present study shows that more than half of the sample was satisfied and very satisfied with services available for the residents (Table3), a finding which contradicts with a study done in Japan $2003^{(32)}$ that revealed that the elderly in elderly homes had a low satisfaction score with the available services. This may be attributed to the fact that elders have lower expectations of provided services or they may be afraid to express their dissatisfaction inspite of repeated assurance.
Physical environment of the elderly home must have special characteristics in order to promote proper functioning and safety of the residents. (31) The present study revealed that about two thirds of the residents (table3) were satisfied and very satisfied with the physical aspect of the homes. This may be due to the impression that elderly home is an obligatory alternative stay and elders have to be satisfied with their surroundings regardless of their quality, also it may be due to ignorance or having little knowledge about the safety precautions needed in the elderly homes. This goes with the finding in a previous study carried on a group of elderly residents in the UK which showed that elders, rated their satisfaction with the home environment as the best. (29)

The present study also found that about two thirds of the residents were satisfied and very satisfied with their personal rights in the homes (table3). This may be due to devaluation of the elderly 
regarding their rights and that their acceptance for the minimal rights. This contradicts with the finding of a study carried out in Taiwan which revealed that the basic traumatic experiences which the residents of elderly homes faced was the restriction of rules and regulations of the institution that affected their autonomy and ability for decision making and which they considered a deprivation of their human rights. ${ }^{(27)}$

Regarding satisfaction with food and meals, the present study revealed that more than half of the sample were satisfied and very satisfied with the meals provided (Table 3). On the other hand, a similar study in USA revealed lower ratings of elderly residents on meals as they boast greater expectations for homes' food quality. (33)

The high ratings of elders to the different satisfaction domains may be a function of other factors. Elders feel a cultural obligation to express gratitude to their care providers and feel that social norms reinforce elders' feelings of inadequacy in judging care experts. Elders may also be reluctant to express negative feelings about care providers, particularly if they except to be dependent upon them in the future. They also feel that residents in homes supported by public funds should perceive the care they receive as a benefit and not want to appear ungrateful. (34) In addition, despite the focus on adverse response to relocation, residence in elderly homes offers numerous benefits as the convenience of having available basic services such as meals, laundry, housekeeping, and personal assistance, and stability of being in a safe setting. So moving to proper elderly home can serve to improve the elderly level of functioning where the home can assist elders to meet their basic daily needs when caregivers are unavailable for any reason. $(35,26,36)$

The present study also investigated the factors related to elders' satisfaction in 
elderly homes. Sex, income, degree of dependency in performing activities of daily living and level of education influence the degree of satisfaction of elderly residents with care provided. (36)

As regards age, the study revealed that the highest mean total satisfaction score was among elders aged more than 80 years (150.6 \pm 33.7$)$ (Table 5). Several studies showed that elderly are more likely to express satisfaction with provided care. (29-34) A number of possible explanations have been put forward: that the older residents often perceive the minimal provided care better than younger ones, that they have lower expectations of care or that they are reluctant to articulate their dissatisfaction.

Regarding the marital status, the present study revealed that the highest mean total satisfaction score was among widowed elders $(145.9 \pm 48.0)$ (Table 5). This may be due to the lack of physical and psychological support among those elders in their own homes.

Elders' economic level can affect the degree of satisfaction with elderly homes. Lack of finance can affect the quality of shelter, nutrition social participation, household assistance and seeking the medical care and services, all of which will have an effect on the needs and demands of the elderly in the quality of institution. (37) This explain the finding in the present study where the highest mean total satisfaction score was among elders with the least

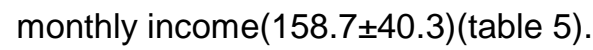

As regards the relation between physical functioning and satisfaction, the present study revealed that the highest mean total satisfaction score was among elders with good physical functioning as detected by Katz and Lawton scales (144.9 \pm 48.3 and $\quad 148.6 \pm 46.2$ respectively) (Table 5). This may explained by the fact that physiologically dependent elders who require more assistance, may be more negative about their residential stay and 
their dependency and discomfort may also make them more dissatisfied. This goes with previous studies which found that elders with better physical functioning rated their care as better. $(38,39,34)$

The degree to which the elder participate in the decision making to live in a elderly home can affect their feelings, and consequently their satisfaction with the home. (25) This goes with the finding in the present study where the highest mean total satisfaction score was among elders whose admission decision was according to their own will (Table 6).

Moreover, the length of stay in the home highly affects the satisfaction of the residents. ( 40-42) Elders who have experience from the long use of a home may be more realistic about expected services, and thus more satisfied. They also have greater familiarity with the process of care and greater familiarity with potential shortcomings in care delivery, and are thus more satisfied. This goes with the results of the present study where the highest mean total satisfaction score was among elders whose length of stay was 5 or more years (Table 6).

Visits from family and friends can buffer the overwhelming of being in an institutional environment, and residents who have more familial visits tend to be more satisfied with their institutionalization. ${ }^{(43)}$ Moreover, elders with poor social relations tend to have a negative outlook on life in general and are reported to be more likely to both view their health as poor and be dissatisfied with their health care. ${ }^{(39,40)}$ This goes with the results of the present study, which showed that the highest mean total satisfaction score was among elders who were visited by their families once per week, and who participated in the social activities in the geriatric home $\quad(173.0 \pm 32.5$ and 169.2 \pm 31.7 respectively) (table 6).

The purpose of the institution is to bring each resident to the highest practical level 
of mental, physical, and psychological well being in an environment that emphasizes residents' rights. So efforts should be directed towards evaluation of elderly home by direct observation of all aspects of care and services with emphasis on the residents' satisfaction.

\section{Conclusion:}

The study concluded that only $8.1 \%$ of the residents were dissatisfied, while nearly half of them $48.8 \%$ were satisfied, and $43.1 \%$ were very satisfied regarding the total satisfaction score of the six domains of satisfaction scale. The least domains of satisfaction were satisfaction with staff and administration of elderly home followed by satisfaction with food and meals. A statistically significant difference was found in the mean total satisfaction score in relation to Lawton scale score, decision and cause of admission, feeling after admission, length of stay, and participation in social activities.

\section{Recommendations:}

Based on the findings of the present study the following can be recommended:

1. Regular monitoring and evaluation of services provided at the elderly homes to ensure a best quality of care at them.

2. In-services training to all staff of elderly homes to increase their skills in dealing with the elders.

3. Collaboration of multimedia with the specialists in gerontology to increase the elderly awareness about the concept of admission to elders' homes and the elderly rights, which may change their degree of satisfaction towards services provided to them. 
Table1: General characteristics of the residents of the elderly homes

\begin{tabular}{|c|c|c|}
\hline variables & $\begin{array}{c}\text { Frequency } \\
(n=123)\end{array}$ & Percent \\
\hline \multicolumn{3}{|l|}{ Sex } \\
\hline Male & 38.2 & 38.2 \\
\hline Female & 61.8 & 61.8 \\
\hline age in years & & \\
\hline $60-$ & 68 & 55.3 \\
\hline 70- & 44 & 35.8 \\
\hline $80+$ & 11 & 8.9 \\
\hline \multicolumn{3}{|c|}{$\mathrm{X} \pm \mathrm{SD}=69.8 \pm 5.86$} \\
\hline \multicolumn{3}{|l|}{ Marital status } \\
\hline Single & 20 & 16.3 \\
\hline Divorced & 26 & 21.1 \\
\hline Widowed & 77 & 62.6 \\
\hline \multicolumn{3}{|l|}{ Having sons/daughters } \\
\hline Yes & 90 & 73.2 \\
\hline No & 33 & 26.8 \\
\hline \multicolumn{3}{|l|}{ Education } \\
\hline Illiterate or read and write & 92 & 74.8 \\
\hline Primary or preparatory & 14 & 11.4 \\
\hline Secondary or above & 17 & 13.8 \\
\hline \multicolumn{3}{|l|}{ Work before admission } \\
\hline Manual worker & 28 & 22.8 \\
\hline Employee & 24 & 19.5 \\
\hline Housewife & 71 & 57.7 \\
\hline \multicolumn{3}{|l|}{ Income/ month } \\
\hline$\leq 200$ & 47 & 38.2 \\
\hline $400-$ & 49 & 39.8 \\
\hline $600+$ & 27 & 22.0 \\
\hline \multicolumn{3}{|l|}{ Source of income } \\
\hline Pension & 115 & 93.5 \\
\hline Children & 6 & 4.9 \\
\hline Social support & 2 & 1.6 \\
\hline \multicolumn{3}{|l|}{ Katz scale for ADL } \\
\hline Independent & 121 & 98.4 \\
\hline Partially dependent & 2 & 1.6 \\
\hline \multicolumn{3}{|l|}{ Lawton scale for IADL } \\
\hline Independent & 108 & 87.8 \\
\hline Partially dependent & 15 & 12.2 \\
\hline
\end{tabular}

$\mathrm{ADL}=$ Activities of daily living

IADL=instrumental Activities of daily living 
Table2: Distribution of the study sample according to admission and social variables.

\begin{tabular}{|c|c|c|}
\hline variables & $\begin{array}{c}\text { Frequency } \\
n=(123)\end{array}$ & $\%$ \\
\hline $\begin{array}{l}\text { Person responsible for admission decision } \\
\text { His/Her own will } \\
\text { Others }\end{array}$ & $\begin{array}{l}92 \\
31\end{array}$ & $\begin{array}{l}74.8 \\
25.2\end{array}$ \\
\hline $\begin{array}{l}\text { cause of admission } \\
\text { no private house } \\
\text { loneliness } \\
\text { no caregiver at home }\end{array}$ & $\begin{array}{l}31 \\
52 \\
40\end{array}$ & $\begin{array}{l}32.5 \\
42.3 \\
25.2\end{array}$ \\
\hline $\begin{array}{l}\text { feeling after admission } \\
\text { Loneliness } \\
\text { Grief \&Misery }\end{array}$ & $\begin{array}{l}64 \\
59\end{array}$ & $\begin{array}{l}52.0 \\
48.0\end{array}$ \\
\hline $\begin{array}{l}\text { length of stay at the home in years } \\
1- \\
3- \\
5+\end{array}$ & $\begin{array}{l}32 \\
51 \\
40\end{array}$ & $\begin{array}{l}26.0 \\
41.5 \\
32.5\end{array}$ \\
\hline \multicolumn{3}{|c|}{$X \pm S D=4.02 \pm 2.83$} \\
\hline $\begin{array}{l}\text { Frequency of family visits } \\
\text { once/week } \\
\text { once/2weeks } \\
\text { once/month }\end{array}$ & $\begin{array}{l}42 \\
40 \\
41\end{array}$ & $\begin{array}{l}34.1 \\
32.5 \\
33.3\end{array}$ \\
\hline $\begin{array}{l}\text { participation in social activities } \\
\text { Yes } \\
\text { No }\end{array}$ & $\begin{array}{l}74 \\
49\end{array}$ & $\begin{array}{l}60.2 \\
39.8\end{array}$ \\
\hline
\end{tabular}

Table 3: Degree of residents' satisfaction with the different satisfaction domains

\begin{tabular}{|c|c|c|c|c|c|c|c|c|c|c|}
\hline \multirow[b]{3}{*}{ Satisfaction domains } & \multicolumn{10}{|c|}{ Degree of satisfaction } \\
\hline & \multicolumn{2}{|c|}{$\begin{array}{c}\text { Very } \\
\text { dissatisfied }\end{array}$} & \multicolumn{2}{|c|}{ Dissatisfied } & \multicolumn{2}{|c|}{ Neutral } & \multicolumn{2}{|c|}{ Satisfied } & \multicolumn{2}{|c|}{$\begin{array}{c}\text { Very } \\
\text { satisfied }\end{array}$} \\
\hline & 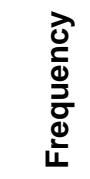 & ○̊ & 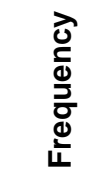 & $\overbrace{}^{\circ}$ & 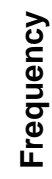 & ○ & 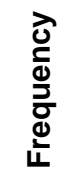 & ○ & 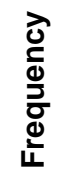 & $\%$ \\
\hline Administrative aspects & 10 & 8.1 & 14 & 11.4 & 29 & 23.6 & 26 & 21.1 & 44 & 35.8 \\
\hline Physical environment & 10 & 8.1 & 16 & 13.0 & 21 & 17.1 & 39 & 31.7 & 37 & 30.1 \\
\hline Available services & 11 & 8.9 & 13 & 10.6 & 28 & 22.8 & 31 & 25.2 & 40 & 32.5 \\
\hline Personal care & 10 & 8.1 & 14 & 11.4 & 30 & 24.4 & 35 & 28.5 & 34 & 27.6 \\
\hline Food services & 10 & 8.1 & 17 & 13.8 & 28 & 22.8 & 41 & 33.3 & 27 & 22.0 \\
\hline Personal rights & 10 & 8.1 & 15 & 12.2 & 20 & 16.3 & 44 & 35.8 & 34 & 27.6 \\
\hline
\end{tabular}


Table 4: Distribution of study sample according to their total satisfaction score

\begin{tabular}{|l|c|c|}
\hline Degree of satisfaction & Frequency & $\%$ \\
\hline Dissatisfied & 10 & 8.1 \\
Satisfied & 60 & 48.8 \\
Very satisfied & 53 & 43.1 \\
Total & 123 & 100 \\
\hline
\end{tabular}

Table 5: Relation between characteristics of the study sample and the mean score of satisfaction domains

\begin{tabular}{|c|c|c|c|c|c|c|c|}
\hline 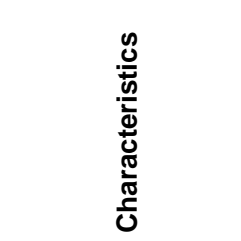 & 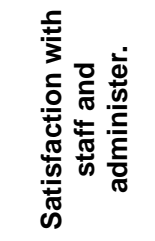 & 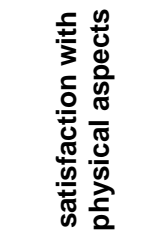 & 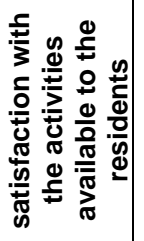 & 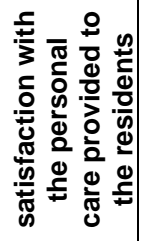 & 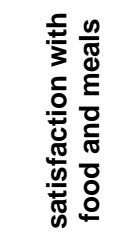 & 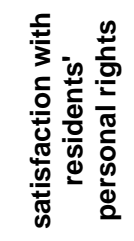 & 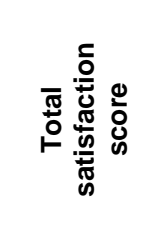 \\
\hline Age (Years) & Mean $\pm S D$ & Mean $\pm S D$ & $\begin{array}{l}\text { Mean } \\
\pm S D\end{array}$ & $\begin{array}{l}\text { Mean } \\
\pm S D\end{array}$ & $\begin{array}{l}\text { Mean } \\
\pm S D\end{array}$ & $\begin{array}{l}\text { Mean } \\
\pm S D\end{array}$ & Mean $\pm S D$ \\
\hline $\begin{array}{l}60- \\
70- \\
80+ \\
\mathrm{P}\end{array}$ & $\begin{array}{l}51.3 \pm 16.9 \\
50.5 \pm 20.1 \\
52.7 \pm 11.9\end{array}$ & $\begin{array}{c}27.8 \pm 9.2 \\
27.2 \pm 10.7 \\
31.0 \pm 7.2\end{array}$ & $\begin{array}{l}17.3 \pm 6.1 \\
17.5 \pm 7.1 \\
18.7 \pm 4.4\end{array}$ & $\begin{array}{l}17.4 \pm 5.8 \\
17.1 \pm 6.7 \\
17.7 \pm 4.1\end{array}$ & $\begin{array}{l}17.2 \pm 5.8 \\
16.4 \pm 6.5 \\
16.7 \pm 5.2\end{array}$ & $\begin{array}{l}14.3 \pm 4.6 \\
13.9 \pm 5.3 \\
13.7 \pm 4.3\end{array}$ & $\begin{array}{c}145.2 \pm 45.3 \\
142.5 \pm 55.0 \\
150.6 \pm 33.7 \\
0.96\end{array}$ \\
\hline $\begin{array}{l}\text { Sex } \\
\text { Male } \\
\text { Female } \\
\text { P }\end{array}$ & $\begin{array}{l}51.8 \pm 15.9 \\
50.7 \pm 18.7\end{array}$ & $\begin{array}{c}27.8 \pm 8.7 \\
27.9 \pm 10.2\end{array}$ & $\begin{array}{l}18.0 \pm 5.9 \\
17.2 \pm 6.5\end{array}$ & $\begin{array}{l}17.7 \pm 5.4 \\
17.0 \pm 6.3\end{array}$ & $\begin{array}{l}16.2 \pm 5.4 \\
17.3 \pm 6.3\end{array}$ & $\begin{array}{l}14.1 \pm 4.5 \\
14.1 \pm 5.1\end{array}$ & $\begin{array}{c}145.6 \pm 43.6 \\
144.2 \pm 50.6 \\
\mathbf{0 . 8 9}\end{array}$ \\
\hline $\begin{array}{l}\text { Marital status } \\
\text { single } \\
\text { divorced } \\
\text { widowed } \\
\mathrm{P} \\
\end{array}$ & $\begin{array}{l}50.5 \pm 20.2 \\
47.7 \pm 15.6 \\
51.6 \pm 17.9\end{array}$ & $\begin{array}{c}26.3 \pm 10.2 \\
27.0 \pm 9.3 \\
28.1 \pm 9.7\end{array}$ & $\begin{array}{l}15.6 \pm 7.1 \\
17.5 \pm 6.2 \\
17.5 \pm 6.1\end{array}$ & $\begin{array}{l}17.1 \pm 6.6 \\
17.2 \pm 5.8 \\
17.2 \pm 6.1\end{array}$ & $\begin{array}{l}16.1 \pm 6.9 \\
15.5 \pm 5.4 \\
17.3 \pm 6.0\end{array}$ & $\begin{array}{l}13.4 \pm 5.6 \\
13.5 \pm 4.9 \\
14.2 \pm 4.7\end{array}$ & $\begin{array}{c}138.4 \pm 53.7 \\
138.3 \pm 45.2 \\
145.9 \pm 48.0 \\
\mathbf{0 . 1 2} \\
\end{array}$ \\
\hline $\begin{array}{l}\text { Income/ month } \\
\leq 200 \\
400^{-} \\
600_{+} \\
P\end{array}$ & $\begin{array}{l}46.0 \pm 20.1 \\
53.7 \pm 15.8 \\
55.2 \pm 14.4\end{array}$ & $\begin{array}{c}25.5 \pm 10.7 \\
28.6 \pm 9.1 \\
30.6 \pm 7.7\end{array}$ & $\begin{array}{l}15.6 \pm 7.1 \\
18.0 \pm 5.5 \\
19.9 \pm 5.4\end{array}$ & $\begin{array}{l}15.7 \pm 6.6 \\
17.8 \pm 5.6 \\
19.2 \pm 4.9\end{array}$ & $\begin{array}{l}15.8 \pm 6.7 \\
17.1 \pm 5.7 \\
18.1 \pm 4.9\end{array}$ & $\begin{array}{l}13.0 \pm 5.3 \\
14.3 \pm 4.5 \\
15.7 \pm 4.1\end{array}$ & $\begin{array}{c}158.7 \pm 40.3 \\
149.6 \pm 43.6 \\
131.7 \pm 53.5 \\
\mathbf{0 . 0 7}\end{array}$ \\
\hline $\begin{array}{l}\text { Katz scale for } \\
\text { ADL } \\
\text { Independent } \\
\text { Partially } \\
\text { dependent } \\
\text { P }\end{array}$ & $\begin{array}{c}51.2 \pm 17.8 \\
44.0 \pm 0.0\end{array}$ & $\begin{array}{l}27.9 \pm 9.7 \\
29.0 \pm 0.0\end{array}$ & $\begin{array}{l}17.5 \pm 6.3 \\
16.0 \pm 0.0\end{array}$ & $\begin{array}{l}17.3 \pm 6.0 \\
16.0 \pm 0.0\end{array}$ & $\begin{array}{l}16.8 \pm 6.0 \\
18.0 \pm 0.0\end{array}$ & $\begin{array}{l}14.1 \pm 4.9 \\
14.0 \pm 0.0\end{array}$ & $\begin{array}{c}144.9 \pm 48.3 \\
137.0 \pm 0.0 \\
\mathbf{0 . 6 6} \\
\end{array}$ \\
\hline $\begin{array}{l}\text { Lawton scale for } \\
\text { IADL } \\
\text { Independent } \\
\text { Partially } \\
\text { dependent } \\
\text { P }\end{array}$ & $\begin{array}{l}52.5 \pm 17.1 \\
40.9 \pm 18.3\end{array}$ & $\begin{array}{c}28.5 \pm 9.3 \\
23.6 \pm 10.9\end{array}$ & $\begin{array}{l}18.0 \pm 6.1 \\
14.3 \pm 6.6\end{array}$ & $\begin{array}{l}17.9 \pm 5.8 \\
13.2 \pm 6.0\end{array}$ & $\begin{array}{l}17.3 \pm 5.8 \\
14.0 \pm 6.3\end{array}$ & $\begin{array}{l}14.5 \pm 4.7 \\
11.3 \pm 5.0\end{array}$ & $\begin{array}{c}148.6 \pm 46.2 \\
117.3 \pm 52.2 \\
\mathbf{0 . 0 3}^{\star}\end{array}$ \\
\hline
\end{tabular}

*Statistically significant $\leq 0.05$

ADL=Activities of daily living

IADL=instrumental Activities of daily living 
Table 6: Relation between some variables and mean score of satisfaction domains

\begin{tabular}{|c|c|c|c|c|c|c|c|}
\hline 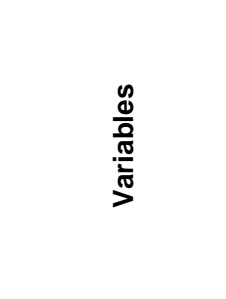 & 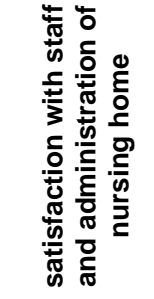 & 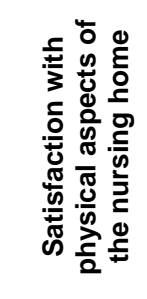 & 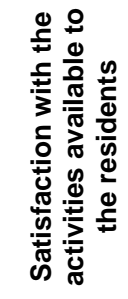 & 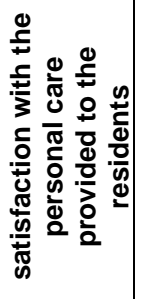 & 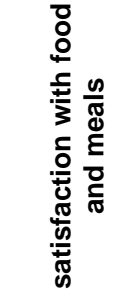 & 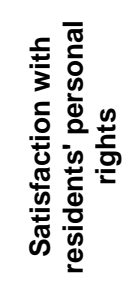 & 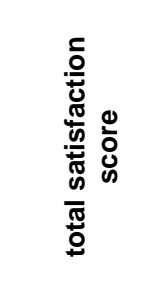 \\
\hline & Mean $\pm S D$ & Mean $\pm S D$ & $\begin{array}{c}\text { Mean } \\
\pm S D \\
\end{array}$ & $\begin{array}{c}\text { Mean } \\
\pm S D \\
\end{array}$ & $\begin{array}{c}\text { Mean } \\
\pm S D\end{array}$ & $\begin{array}{c}\text { Mean } \\
\pm S D\end{array}$ & Mean $\pm S D$ \\
\hline $\begin{array}{l}\text { Decision of } \\
\text { admission to } \\
\text { the home } \\
\text { His/Her own will } \\
\text { Others } \\
\text { P }\end{array}$ & $\begin{array}{l}55.4 \pm 15.6 \\
39.2 \pm 16.7\end{array}$ & $\begin{array}{l}30.1 \pm 8.7 \\
21.5 \pm 8.9\end{array}$ & $\begin{array}{l}19.0 \pm 5.7 \\
13.4 \pm 5.3\end{array}$ & $\begin{array}{l}18.7 \pm 5.4 \\
12.6 \pm 5.4\end{array}$ & $\begin{array}{l}18.0 \pm 5.4 \\
13.8 \pm 5.6\end{array}$ & $\begin{array}{l}15.0 \pm 4.4 \\
11.6 \pm 4.8\end{array}$ & $\begin{array}{c}156.0 \pm 42.9 \\
112.0 \pm 48.6 \\
\mathbf{0 . 0 0}^{*}\end{array}$ \\
\hline $\begin{array}{l}\text { Feeling after } \\
\text { admission to } \\
\text { the home } \\
\text { Loneliness } \\
\text { Grief \& misery } \\
\text { P }\end{array}$ & $\begin{array}{l}59.1 \pm 14.4 \\
42.4 \pm 16.8\end{array}$ & $\begin{array}{l}31.4 \pm 8.3 \\
24.0 \pm 9.5\end{array}$ & $\begin{array}{l}20.1 \pm 4.9 \\
14.7 \pm 6.4\end{array}$ & $\begin{array}{l}20.1 \pm 4.9 \\
14.5 \pm 5.7\end{array}$ & $\begin{array}{l}19.8 \pm 5.0 \\
13.7 \pm 5.3\end{array}$ & $\begin{array}{l}16.2 \pm 3.9 \\
11.9 \pm 4.8\end{array}$ & $\begin{array}{c}162.3 \pm 34.3 \\
82.5 \pm 36.1 \\
\mathbf{0 . 0 0 *} \\
\end{array}$ \\
\hline $\begin{array}{l}\text { Cause of } \\
\text { admission } \\
\text { No private home } \\
\text { Feeling lonely } \\
\text { No caregiver at } \\
\text { home } \\
\text { P }\end{array}$ & $\begin{array}{l}42.7 \pm 18.9 \\
55.8 \pm 17.0 \\
51.6 \pm 15.3\end{array}$ & $\begin{array}{c}25.1 \pm 11.2 \\
30.0 \pm 9.3 \\
27.2 \pm 8.2\end{array}$ & $\begin{array}{l}15.7 \pm 7.5 \\
19.1 \pm 6.0 \\
16.9 \pm 5.2\end{array}$ & $\begin{array}{l}15.2 \pm 6.5 \\
19.0 \pm 5.9 \\
16.8 \pm 5.1\end{array}$ & $\begin{array}{l}14.1 \pm 6.1 \\
18.5 \pm 6.0 \\
16.8 \pm 5.0\end{array}$ & $\begin{array}{l}12.1 \pm 5.1 \\
15.3 \pm 4.8 \\
14.1 \pm 4.2\end{array}$ & $\begin{array}{c}124.7 \pm 52.5 \\
157.8 \pm 46.7 \\
143.4 \pm 40.6 \\
\mathbf{0 . 0 1}^{*} \\
\end{array}$ \\
\hline $\begin{array}{l}\text { length of stay } \\
\text { at the home in } \\
\text { years } \\
1- \\
3- \\
5+ \\
\text { p }\end{array}$ & $\begin{array}{l}41.4 \pm 19.2 \\
54.8 \pm 14.9 \\
54.3 \pm 17.0\end{array}$ & $\begin{array}{c}23.3 \pm 11.0 \\
29.5 \pm 8.2 \\
29.5 \pm 9.2\end{array}$ & $\begin{array}{l}14.5 \pm 7.3 \\
18.8 \pm 5.3 \\
18.2 \pm 5.8\end{array}$ & $\begin{array}{l}15.2 \pm 6.8 \\
17.8 \pm 5.2 \\
18.3 \pm 5.8\end{array}$ & $\begin{array}{l}13.9 \pm 6.4 \\
18.3 \pm 5.0 \\
17.4 \pm 6.1\end{array}$ & $\begin{array}{l}12.1 \pm 5.7 \\
15.2 \pm 4.0 \\
14.3 \pm 4.7\end{array}$ & $\begin{array}{c}120.4 \pm 54.4 \\
151.9 \pm 46.7 \\
154.4 \pm 39.3 \\
\mathbf{0 . 0 2}^{*}\end{array}$ \\
\hline $\begin{array}{l}\text { Frequency of } \\
\text { family visits } \\
\text { once/week } \\
\text { once/2weeks } \\
\text { once/month } \\
\text { P }\end{array}$ & $\begin{array}{l}62.1 \pm 12.5 \\
43.7 \pm 16.6 \\
47.1 \pm 17.9\end{array}$ & $\begin{array}{c}33.4 \pm 6.2 \\
24.2 \pm 10.1 \\
25.8 \pm 9.7\end{array}$ & $\begin{array}{l}20.5 \pm 4.2 \\
15.7 \pm 6.5 \\
16.3 \pm 6.9\end{array}$ & $\begin{array}{l}20.1 \pm 4.8 \\
15.5 \pm 6.1 \\
16.3 \pm 6.1\end{array}$ & $\begin{array}{l}20.4 \pm 4.5 \\
14.9 \pm 5.7 \\
15.2 \pm 6.1\end{array}$ & $\begin{array}{l}16.6 \pm 3.2 \\
12.3 \pm 4.8 \\
13.4 \pm 5.2\end{array}$ & $\begin{array}{c}173.0 \pm 32.5 \\
126.1 \pm 47.1 \\
134.0 \pm 49.4 \\
\mathbf{0 . 2}\end{array}$ \\
\hline $\begin{array}{l}\text { participation in } \\
\text { social activities } \\
\text { yes } \\
\text { no } \\
\text { P }\end{array}$ & $\begin{array}{l}59.8 \pm 12.1 \\
38.1 \pm 16.7\end{array}$ & $\begin{array}{l}32.6 \pm 6.7 \\
20.8 \pm 9.0\end{array}$ & $\begin{array}{l}20.6 \pm 4.3 \\
12.9 \pm 6.0\end{array}$ & $\begin{array}{l}20.1 \pm 4.2 \\
13.0 \pm 5.7\end{array}$ & $\begin{array}{l}19.7 \pm 4.3 \\
12.5 \pm 5.5\end{array}$ & $\begin{array}{l}16.4 \pm 3.2 \\
10.6 \pm 4.7\end{array}$ & $\begin{array}{c}169.2 \pm 31.7 \\
107.9 \pm 44.6 \\
\mathbf{0 . 0 0}^{\star}\end{array}$ \\
\hline
\end{tabular}

${ }^{*}$ Statistically significant $\leq 0.05$ 


\section{REFERENCES:}

1- Lueckenotte A. Gerontological Nursing.2nd ed. Philadelphia: Mosby comp;2000.p.799-810.

2- World Health Organization. Population and its growth. WHO Tech Resp Ser No., Geneva:WHO; 1997.p.10-11.

3- United State Bureau of the Census. International Data Base. Washington DC: International programs center;1996.

4- Scott JC. Research in long -term Care: Isues, Dilemmas, and challenges from the public purchaser's perspective. Medical Care. 2004; 42(4):11-18.

5- Fiveash B. The experience of nursing home life. Int J Nursing Pract. 1998; 4(3): 166-174.

6- Liao Y, McGee D, Cooper R. Quality of last year of life of older adults: 1986 VS 1993.JAMA. 2000; 283 (4): 512518.

سيد طلبة وكيل أول وزارة الشئون الاجتماعية

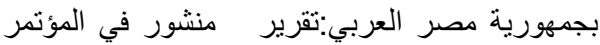
الاقليمى الثاني لر عاية المسنين جامعة حلوان ، 2001 فئنير

8- Margolis SA, Reed RL. Institutionalization older adults in a health district in the United Arab Emirates: health status and utilization rate. J Gerontol. 2001; 47(3):161-167

9- Al-Nasir F, Al- Hadded M. levels of disability among the elderly in institutionalized and home- based care in Bahrain. Eastern Mediterranean Health Journal. 1999;(2): 247-259

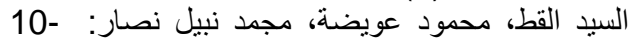
الرعاية الصحية للمسنين." دليل التئدة التدريب للعاملين

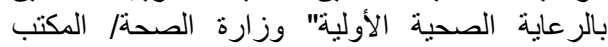
الاقليمى لمنظمة الصحة العالمية، 1998 صفحة العة العة العة

11- Anderson M, Gottfries CG. Nursing Home Care: Factors Influencing the quality of life in a restricted life situation. Aging. 2004; 23(3): 229-239.
12- Nick TJ. What is Your Life Like Now? Loneliness and Elderly Individuals Residing in Nursing Homes. J Geronto Nurs.2000;26(8):15-19.

13- Sitzia J, Wood N. Patient satisfaction: A review of issues and concepts. Soc Sci Med. 1997; 45: 1829-1843.

14- Margaret $P$. The Nursing Home of the Future. Are you Ready? Nursing Homes. 2002 ; (3):31-33.

15- Taylor S A. Distinguishing service quality from patient satisfaction in developing health care marketing strategies. Health and Hospital service Adminstration. 1994; 39 (2):230-234.

16- Dansky K H. Discriminate Analysis: A Technique for adding value to Patient Satisfaction Surveys. Health and Hospital Service Adminstration. 1996; 41(4): 401-403.

17- Mezey M, Fulmer T. Quality care fore the frail elderly. Nurs Outlook. 1998; 46: 291-292.

18- United Nations. The sex and age distribution of the world populations. The 1994 revision. New York: United Nations-Department of Economic and Social Information and Policy Analysis, Population Division; 1994.

19- Katz S, Ford AB, Moskouitz RW. Studies of illness in the aged. The index of ADL; a standardized measure of biological and psychological functions. JAMA. 1963; 185: 914-919.

20- Lawton HP, Brody EM. Assessment of older people: self maintaining and instrumental activities of daily living. Gerontologist. 1969; 1 (9): 179- 186.

21- Nursing Home Satisfaction Survey- A Consumer Tool, Bureau of Health Quality Management, Commonwealth of Massachusetts, department of Public Health,23/4/2006 
http://www.mass.gov/dph/dhcq/nhsurvey-overview.htm

22- Administration on aging (2004). Older Americans 2004.Keu indicator of wellbeing Retrieved January 13, 2006 from http://agingstats.gov.

23- Elderweb. (2005). LTC backwards and forward. Retrieved January 13, 2006, from www.elderweb. com.

24- Centers for Disease Control and Prevention (CDC). (2003). Health: United States 2003. Trend tables and chart book. Hyattsville, MD: department of Health and Human services.

25- Hagen, B., Esther, C.A., Ikuta, R.,William,R., Navenec,C.C., \&Aho, M. Antipsychotic drug use in Canadian long term care facilities: Prevalence and patterns following resident relocation. International pschogeriatrics.2005;17(2):179-193.

26- Mahfouz M. Quality of life for institutionalized elders. Unpublished thesis, Master degree, Alexandria: University of Alexandria, Faculty of nursing 2005.

27- Tseng S, Wang R. Quality of life and related factors among elderly nursing home residents in Southern Taiwan. Public Health Nurs. 2001; 18 (5): 304311.

28- Hall JA, Feldstein M, Fretwell MD, Rowe JW, Epstein AM. Older patients' health status and satisfaction with medical care in an $\mathrm{HMO}$ population. Med Care. 1990; 28: 261-270.

29- Owens D, Batchelor C. Patients satisfaction and the elderly. Soc Sci Med. 1996; 42: 1483-1491.

30- Rubinstein RL. Resident Satisfaction, Quality of life, lived Experiences as Domains to be assessed in long Term Care. In: Cohen Mansfield J, Ejaz FK, Werner P, eds. Satisfaction surveys in long-term care. New york: Springer ;2001.p.13-28.

31- Raftpoulos V. Does depression correlate with elderly patient satisfaction and perceived quality of care? Annals of General Hospital Psychiatry. 2003; 2: 87.

32- Ewada S, Weheida S Abou-Donia S. Social -environment adjustment and life satisfaction of institutionalized and non institutionalized elderly. $2^{\text {nd }}$ International Scientific Nursing Congress on Health Promotion, Alexandria: University of Alexandria, Faculty of Nursing, 1991.

33- Clark PA, Kaldenberg DO, Drain M, Wolosin R. Elderly inpatients' priorities for acute care service quality. International Journal of Health Care Quality Assurance. 2004; 17: 92-104.

34- Guirguis WW, Mokhtar SA, Al Torkey MM, Khalaf AA. Patients satisfaction with hospital services: determinants and level in a hospital in Kuwait. The Journal of the Egyptian Public Health Association. 1992; 67: 87-103.

35- Castle, N.G. Relocation of the elderly. Medical Care Research and Review.2001; 58(3), 291-333.

36- Kane RL, Kane RA. Assessment in long -term Care. Annu Rev Public Health. 2000; 21(6): 659-686.

37- Alt- White A. An interdisciplinary approach to improving the quality of nursing home residents. Nursing Connections 2000; 6(4):51-59.

38- Fried T, Doorn C, O'Leary J, Tinette M, Drickamer M. Older persons' perceptions of home and hospital as sites of treatment for acute illness. Am J Med. 1999; 107: 317-323.

39- Rahmquist M. Satisfaction in relation to age, health status and other background factors: a model for comparison of care units. Intern $\mathrm{J}$ 
Qual Health Care. 2001; 13: 385-390.

40- Tucker JL, Kelley VA. The influence of socio-demographic characteristics on satisfaction. Mil Med. 2000; 165: 72-76.

41- Shmuely Y, Baumgarten M, Rovner B, Berlin J. Predictors of improvement in health related quality of life among elderly patients with depression. Psychogeriatr. 2001; 13: 63-73.
42- Raftopoulos V. A grounded theory for elders' satisfaction with quality of care. ICUS Nurs Web J. 2005; 22: 1-15.

43- Inagaki T, Yamamoto T, Yoshida E, Inagaki A, Miimi $T$, Ojika. Comprehensive social assessment of the elderly in institutions, particularly in terms of social life. Nippon Ronen Igakkai 2003; 30(11):947-52. 